\title{
The relationship between the BRAF p.V600E mutation and a family history of CRC in the early- onset CRC cases from the Australasian Colon Cancer Family Study
}

\author{
DD Buchanan ${ }^{1 *}$, AK Win ${ }^{2}$, R Walters ${ }^{1}$, MD Walsh ${ }^{1}$, M Clendenning ${ }^{1}$, B Nagler ${ }^{1}$, E Pavluk ${ }^{1}$, SA Pearson ${ }^{1}$, C Rosty ${ }^{1,3}$, \\ J Maskiell², JL Hopper ${ }^{2}$, MA Jenkins'², JP Young ${ }^{1}$ \\ From Familial Aspects of Cancer 2011 Research and Practice: A combined meeting of kConFab, Australian \\ Breast Cancer Family Study, Australian Colorectal Cancer Family Study, Australian Ovarian Cancer Study, \\ Family Cancer Clinics of Australia and New Zealand and kConFab \\ Kingscliff, Australia. 23-26 August 2011
}

\section{Background}

The BRAF p.V600E somatic mutation is present in approximately $10-20 \%$ of unselected colorectal cancer (CRC) and $30 \%-75 \%$ of CRCs demonstrating high levels of microsatellite instability (MSI-H). Currently, testing for the BRAF p.V600E mutation is undertaken to exclude Lynch syndrome in MSI-H CRCs that demonstrate loss of the MLH1 and PMS2 proteins by IHC. However, recent evidence suggests that the BRAF p. V600E mutation is associated with a familial predisposition to serrated neoplasia, an increased risk of CRC and possibly extra-colonic cancers in relatives. The aim of this study was to determine 1) if early-onset CRC with the $B R A F$ p.V600E mutation is associated with a family history of CRC, and 2) if pathological features of $B R A F$ positive CRCs associate with CRC development in relatives.

\section{Methods}

Population-based recruitment of probands into the Australasian Colon Cancer Family Study between 1997 and 2006 was undertaken for newly diagnosed CRC irrespective of any family history of cancer but limited to a first primary adenocarcinoma of the colon or rectum between the ages of 18-60yrs. Patients with Lynch syndrome and MutYH associated polyposis were excluded

'Familial Cancer Laboratory, Queensland Institute of Medical Research, Bancroft Centre, Herston QLD 4006, Australia

Full list of author information is available at the end of the article from the analysis. The BRAF p.V600E mutation was determined using a previously described allele-specific PCR assay on DNA from formalin-fixed paraffin embedded colorectal cancer tissue.

\section{Results}

The average age of onset for the 709 probands (49.5\% female) was $46.3 \mathrm{yrs} \pm 7.9 \mathrm{yrs}(\mathrm{SD})$ with a range of $18 \mathrm{yrs}$ to 60yrs. A history of CRC in at least one first degree relative (FDR) or second degree relative (SDR) was reported in $39.5 \%$ (280/709) of the probands. The BRAF p.V600E mutation was present in 54/709 (7.6\%) CRCs. Overall, probands with a $B R A F$ p.V600E positive CRC were less likely to have a FDR with CRC than probands with a $B R A F$ wildtype $C R C(\mathrm{OR}=0.42,95 \% \mathrm{CI}=0.16-1.09$; $\mathrm{P}=0.07)$ regardless of MSI status. Among the probands with a $B R A F$ p.V600E mutated CRC, the mean age at diagnosis was significantly older for probands with a CRC-affected FDR or SDR (50.4 years, 95\%CI=47.153.7) when compared to probands without a family history ( 44.0 years, $95 \% \mathrm{CI}=40.7-42.3 ; P=0.02$ ). The odds (risk) of having a family history of CRC significantly increased $11 \%$ per year of age (OR 1.11; 95\% CI 1.01 $1.21 ; \mathrm{P}=0.02)$ in probands with a $B R A F \mathrm{p} . \mathrm{V} 600 \mathrm{E}$ mutation positive CRC. When considering only BRAF p. V600E positive CRC, a mucinous histology was increased 4.4 fold in probands with a FDR or SDR with CRC $(n=17)$ when compared to probands without a family history of CRC $(n=37)$, although this was not 
significantly different $(\mathrm{OR}=4.40 ; 95 \% \mathrm{CI}=0.59-32.62$; $\mathrm{P}=0.15)$.

\section{Conclusions}

In this study of early-onset CRC, we describe evidence for a relationship between the BRAF p.V600E mutation and a family history of CRC that is related to an increasing age of CRC onset. These findings, in conjunction with observations suggesting certain pathological features are associated with a family history of CRC in $B R A F$ p.V600E mutated CRC warrant further investigation.

\section{Author details}

'Familial Cancer Laboratory, Queensland Institute of Medical Research, Bancroft Centre, Herston QLD 4006, Australia. ${ }^{2}$ Centre for MEGA Epidemiology, School of Population Health, University of Melbourne, Carlton VIC 3053, Australia. ${ }^{3}$ Molecular and Cellular Pathology, University of Queensland, Herston, QLD 4006, Australia.

Published: 12 April 2012

- Convenient online submission

- Thorough peer review

- No space constraints or color figure charges

- Immediate publication on acceptance

- Inclusion in PubMed, CAS, Scopus and Google Scholar

- Research which is freely available for redistribution 